\title{
A STUDY OF GASTRIC PEPSIN IN VARIOUS DISEASES
}

\author{
By CLINTON R. MULLINS and CHARLES A. FLOOD \\ (From the Departments of Surgery and Medicine, College of Physicians and Surgeons, \\ Columbia University, and the Presbyterian Hospital, New York City)
}

(Received for publication June 12, 1935)

The study of gastric pepsin has resulted in rather conflicting reports in the literature. Its significance in estimating the secretory capacity of the stomach has apparently not been widely recognized. In studying the causes of chronicity of peptic ulcer, we have gained the impression that increased pepsin concentration in the gastric contents plays a rôle in delaying healing of artificial defects in the stomach (1). In view of these facts, it was felt desirable to study the secretion of pepsin in patients with and without disease of the stomach.

The results are reported in this paper.

\section{METHOD}

The gastric contents were obtained one hour after an Ewald meal, in most instances without a fasting expression. In a small group fasting samples were taken before the test meal. The juice was filtered immediately, diluted and kept in the ice box. The pepsin determinations were done within three hours as a rule, though values for the diluted specimens were found to remain unchanged up to three days.

Free and total acidity were titrated with $1 \mathrm{cc}$. of the filtered juice against N/100 sodium hydroxide. Toepfer's reagent was used as the indicator for free acid and phenolphthalein solution for total acid.

The peptic activity of the gastric contents was determined by the method of Anson and Mirsky (2). This depends upon the digestion of hemoglobin by pepsin, the end-product being tyrosine. The procedure in detail is as follows. One cubic centimeter of the filtered gastric juice is diluted with $\mathrm{N} / 10 \mathrm{HCl}$, the dilution being usually between 1:5 and 1:15 and selected in most instances by the acidity of the specimen. The final colorimetric reading must fall between 10 and $30 \mathrm{~mm}$., the standard being at $20 \mathrm{~mm}$. At times the preliminary readings do not fall within this range; then the test must be repeated with a different dilution; but with experience this is seldom necessary.

To 5 cc. of 2 per cent carbon monoxide hemoglobin in $.06 \mathrm{~N} \mathrm{HCl}$ in a test tube is added $1 \mathrm{cc}$. of the diluted gastric juice. Digestion is allowed to proceed for five minutes in a constant temperature water bath at $35.5^{\circ} \mathrm{C}$., after which $10 \mathrm{cc}$. of 4 per cent trichloracetic acid are added, which stops the digestion by precipitating the remaining hemoglobin. The mixture is filtered through fine paper. To $3 \mathrm{cc}$. of the clear filtrate in a $50 \mathrm{cc}$. Erlenmeyer flask are added $20 \mathrm{cc}$. of distilled water, $1 \mathrm{cc}$. of $3.85 \mathrm{~N}$ sodium hydroxide and $1 \mathrm{cc}$. of phenol reagent. The standard consists of 20 cc. of distilled water, $3 \mathrm{cc}$. of $\mathrm{N} / 10 \mathrm{HCl}$ containing $0.15 \mathrm{mgm}$. of tyrosine, $1 \mathrm{cc}$. of $3.85 \mathrm{~N}$ sodium hydroxide and $1 \mathrm{cc}$. of phenol reagent. The blue colors are compared after from five to ten minutes.

In order to determine the amount of coloring matter already in the specimen, a blank is run through with the original as follows: hemoglobin $5 \mathrm{cc} .+10 \mathrm{cc}$. trichloracetic acid $+1 \mathrm{cc}$. diluted juice, given five minutes digestion. To $3 \mathrm{cc}$. of the filtrate from this are added $14 \mathrm{cc}$. distilled water, $3 \mathrm{cc} . \mathrm{N} / 10 \mathrm{NaOH}, 3 \mathrm{cc}$. of the standard tyrosine solution, 1 cc. $3.85 \mathrm{NaOH}$ and 1 cc. phenol reagent. The difference between this solution and the standard gives the amount of extraneous coloring matter in the specimen being tested. This is subtracted from the original and the result, multiplied by the dilution, gives the units of pepsin, P. U., of the original specimen. The formula is : P. U. $=(0.0195 / x)-0.000147$ where $\mathbf{x}$ is the colorimeter reading. In practice, a table containing all the values for readings between 10 and 30 is used.

In order to convert these results into more significant values, we have translated them into milligrams of pepsin $(1: 4,000)$ per cubic centimeter as suggested by Helmer, Fouts, and Zerfas (3). Repeated determinations on a 0.1 per cent solution of commercial pepsin (Armour \& Co., 
$1: 4,000$ ) have given an average $P$. U. of 0.001700 .

\section{RESULTS}

For purposes of tabulation the cases have been divided into six groups as follows:

Miscellaneous group (Table I). This includes 28 cases on the general medical and surgical wards

TABLE I

Secretion of pepsin in response to an Ewald meal in 27 patients with miscellaneous conditions

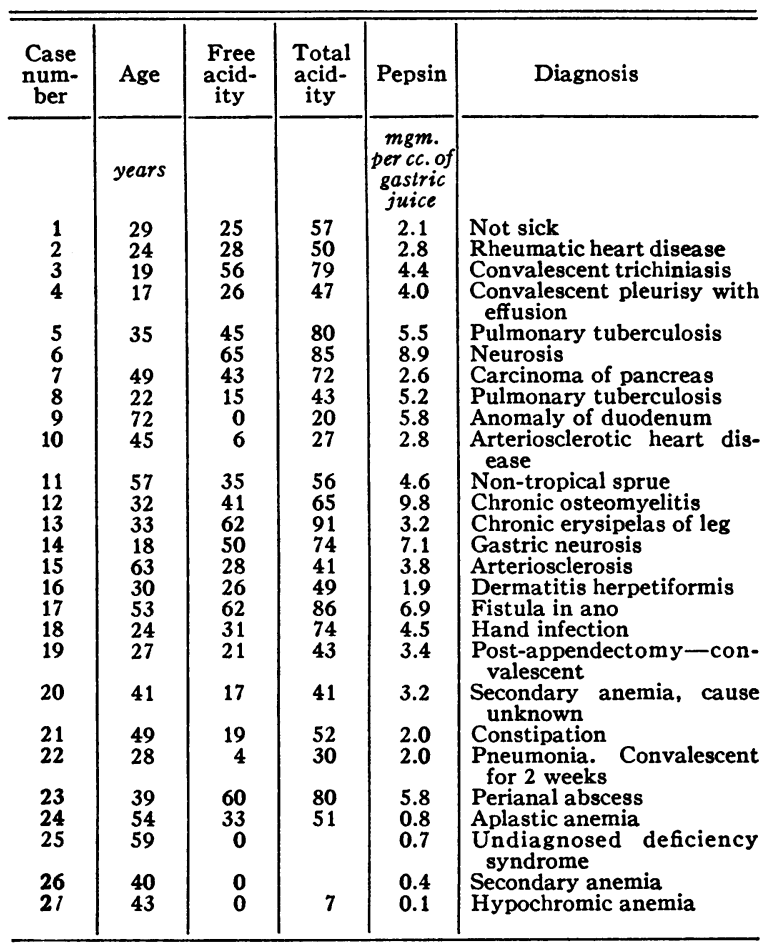

with no known disease of the stomach or duodenum. The median value for these cases is 3.6 mgm. pepsin per cc. Interesting values are seen in Case 9 with achlorhydria and slightly high pepsin; Case 11 with sprue-like deficiency, hyperchromic anemia, normal acid and slightly high pepsin; Case 24 with an aplastic type of anemia, normal acid and very low pepsin; and Cases 25, 26 , and 27 with anemia, achlorhydria and low pepsin concentrations. The last four cases fall within the range seen in pernicious anemia (see Table V). The mean free acid value for this miscellaneous group was 31 .

Duodenal ulcer group (Table II). These were patients who had not been operated upon but were
TABLE II

Secretion of pepsin in response to an Ewald meal in thirty-three patients with duodenal ulcer

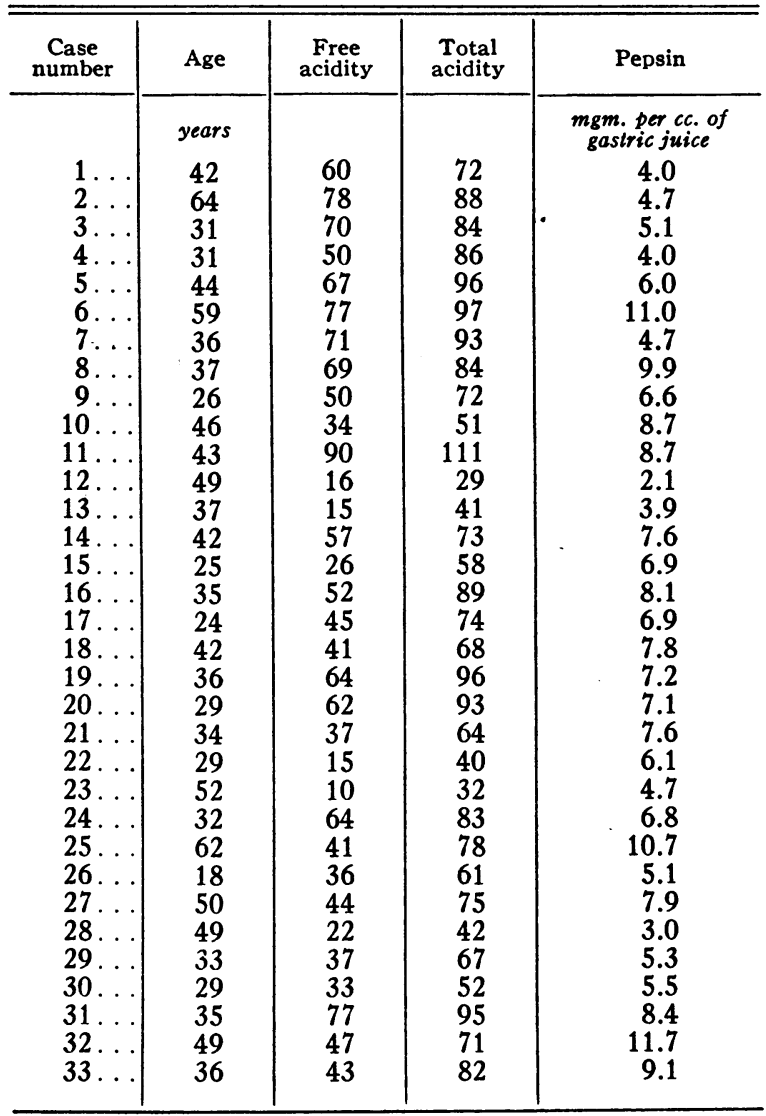

undergoing medical treatment in the hospital. All except one (Case 11) were having symptoms at the time of observation. The median value for this group of 33 cases was $6.75 \mathrm{mgm}$. of pepsin per cc. or slightly over twice that of the miscellaneous group. Variations were fairly marked, ranging from 2.1 to $11.7 \mathrm{mgm}$. The mean free acid value was 47.5 .

Postoperative ulcer cases (Table III). There were only five patients in this group, with values between 0 and $3.4 \mathrm{mgm}$. Three had been subjected to partial gastrectomy 19 years, 15 months and 3 weeks before, respectively. The latter case showed no pepsin. Cases 1 and 2 had had previous short-circuiting operations, and these, as well as Case 4, were suffering from ulcer-like symptoms at the time the analyses were done.

Carcinoma of the stomach (Table IV). This group comprises six patients. The diagnosis was 
TABLE III

Secretion of pepsin in response to an Ewald meal in five postoperative ulcer patients

\begin{tabular}{|c|c|c|c|c|c|}
\hline $\begin{array}{c}\text { Case } \\
\text { number }\end{array}$ & Age & $\underset{\begin{array}{c}\text { Free } \\
\text { acidity }\end{array}}{\text {. }}$ & $\begin{array}{c}\text { Total } \\
\text { acidity }\end{array}$ & Pepsin & Diagnosis \\
\hline $1 \ldots$ & $\begin{array}{c}\text { years } \\
39\end{array}$ & 18 & 32 & $\begin{array}{c}\text { mgm. per cc. gastric } \\
\text { juice } \\
3.4\end{array}$ & $\begin{array}{l}\text { Old gastro-enterostomy (10 years). Gastric ulcer. Jejunal ulcer (?) } \\
\text { Old duodenal ulcer. }\end{array}$ \\
\hline $2 .$. & 29 & 14 & 42 & 2.5 & Gastro-enterostomy and exclusion of antrum ( 9 months). Jejunal ulcer \\
\hline 3.. & 37 & 0 & 7 & 0 & Sub-total gastrectomy for duodenal ulcer (3 weeks). \\
\hline 4. & 41 & 0 & 3 & 0.5 & Partial gastrectomy for duodenal ulcer (15 months). Jejunal ulcer (?). \\
\hline 5. & 29 & 12 & 37 & 1.2 & Partial gastrectomy for gastric ulcer (19 years). \\
\hline
\end{tabular}

TABLE IV

Pepsin values in six cases of carcinoma of stomach after an Ewald meal

\begin{tabular}{|c|c|c|c|c|}
\hline $\begin{array}{c}\text { Case } \\
\text { number }\end{array}$ & Age & $\begin{array}{c}\text { Free } \\
\text { acidity }\end{array}$ & $\begin{array}{l}\text { Total } \\
\text { acidity }\end{array}$ & Pepsin \\
\hline & years & & & $\underset{\text { gastric juice }}{\text { mgm. per } c c . \text { of }}$ \\
\hline $\begin{array}{l}1 \ldots \\
2 \ldots \\
3 \ldots \\
4 \ldots \\
5 \ldots \\
6 \ldots\end{array}$ & $\begin{array}{l}53 \\
59 \\
65 \\
67 \\
59 \\
71\end{array}$ & $\begin{array}{l}0 \\
0 \\
0 \\
0 \\
5 \\
0\end{array}$ & $\begin{array}{r}6 \\
49 \\
8 \\
13 \\
21 \\
17\end{array}$ & $\begin{array}{l}1.0 \\
0.1 \\
0.4 \\
0.5 \\
6.5 \\
1.0\end{array}$ \\
\hline
\end{tabular}

subsequently confirmed by operation in all except Case 1 in which the $x$-ray and clinical picture were typical (the patient refused operation). Case 5 was the only one showing free acid, accompanied by an elevated pepsin value. In the others the pepsin was quite low.

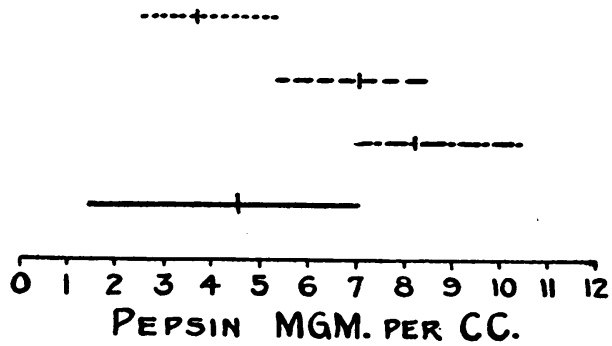

Fig. 1. Comparison of Medians and Interquartile Ranges of Amount of Pepsin Secretion in Mgm. Per cc. of Gastric Juice in Patients with Miscellaneous Conditions $(\cdots \cdots)$, in Patients with Duodenal Ulcer (- . - -), and in the Total Group (in Response to an Ewald Meal; and in Fasting Patients (-. - - - ) (the Total Group Does Not Include the Fasting Patients).
Pernicious anemia (Table V). This includes ten patients, all with achlorhydria and very low total acid. The pepsin values range from 0 to $0.5 \mathrm{mgm}$., nine cases showing only traces.

TABLE V

Pepsin secretion in ten cases of pernicious anemia after an Ewald meal

\begin{tabular}{r|c|c|c|c}
\hline $\begin{array}{c}\text { Case } \\
\text { number }\end{array}$ & Age & $\begin{array}{c}\text { Free } \\
\text { acidity }\end{array}$ & $\begin{array}{c}\text { Total } \\
\text { acidity }\end{array}$ & Pepsin \\
\cline { 2 - 4 } $1 \ldots$ & years & & & $\begin{array}{c}\text { mgm. per cc. of } \\
\text { gastric juice }\end{array}$ \\
$2 \ldots$ & 51 & 0 & 2 & 0 \\
$3 \ldots$ & 35 & 0 & 5 & 0.1 \\
$4 \ldots$ & 59 & 0 & 2 & 0.1 \\
$5 . .$. & 55 & 0 & 4 & 0.1 \\
$6 \ldots$ & 42 & 0 & 4 & 0.2 \\
$7 \ldots$ & 32 & 0 & 3 & 0.1 \\
$8 \ldots$ & 65 & 0 & 3 & 0.3 \\
$9 \ldots$ & 55 & 0 & 4 & 0.1 \\
$10 . .$. & 48 & 0 & 3 & 0.5 \\
\hline
\end{tabular}

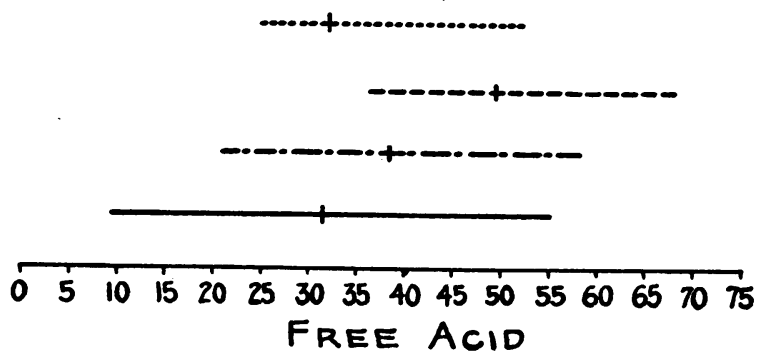

Fig. 2. Comparison of Medians and Interquartile Ranges of Amount of Free Acid (cc. N/10 Per 100 cc.) in Patients with Miscellaneous Conditions $(\cdots \cdots)$, in Patients with Duodenal Ulcers (----), and in the Total Group (- $\longrightarrow$, in Response to an Ewald Meal; and in Fasting Patients (- - - - - - ) (the Total Group Does Not Include Fasting Patients). 
Fasting expressions (Table VI). These 16 observations are presented to show the extreme variation in fasting pepsin concentration. Ex-

TABLE VI

Pepsin content of fasting gastric secretion in sixteen individuals

\begin{tabular}{|c|c|c|c|c|c|}
\hline $\begin{array}{l}\text { Case } \\
\text { num- } \\
\text { ber }\end{array}$ & Age & $\begin{array}{l}\text { Free } \\
\text { acid- } \\
\text { ity }\end{array}$ & $\begin{array}{l}\text { Total } \\
\text { acid- } \\
\text { ity }\end{array}$ & Pepsin & Diagnosis \\
\hline & years & & & $\begin{array}{l}\text { mgm. per } \\
\text { cc. of gas- } \\
\text { tric juice }\end{array}$ & \\
\hline $\begin{array}{l}1 \\
2 \\
3 \\
4 \\
5 \\
6\end{array}$ & $\begin{array}{l}44 \\
31 \\
31 \\
36 \\
37 \\
55\end{array}$ & $\begin{array}{r}128 \\
26 \\
43 \\
18 \\
59 \\
55\end{array}$ & $\begin{array}{r}142 \\
36 \\
51 \\
26 \\
71 \\
70\end{array}$ & $\begin{array}{r}12.1 \\
8.0 \\
7.4 \\
5.8 \\
9.8 \\
6.1\end{array}$ & $\begin{array}{l}\text { Duodenal ulcer } \\
\text { Duodenal ulcer } \\
\text { Duodenal ulcer } \\
\text { Duodenal ulcer } \\
\text { Duodenal ulcer } \\
\text { Carcinoma of } \\
\text { stomach }\end{array}$ \\
\hline $\begin{array}{l}7 \\
8\end{array}$ & $\begin{array}{l}29 \\
19\end{array}$ & $\begin{array}{l}58 \\
11\end{array}$ & $\begin{array}{l}88 \\
27\end{array}$ & $\begin{array}{l}8.1 \\
4.6\end{array}$ & $\begin{array}{l}\text { Not sick } \\
\text { Convalescent tri- } \\
\text { chiniasis }\end{array}$ \\
\hline $\begin{array}{r}9 \\
10 \\
11 \\
12 \\
13 \\
14 \\
15\end{array}$ & $\begin{array}{l}56 \\
40 \\
38 \\
16 \\
35 \\
60 \\
35\end{array}$ & $\begin{array}{r}0 \\
48 \\
30 \\
0 \\
32 \\
60 \\
24\end{array}$ & $\begin{array}{r}4 \\
63 \\
50 \\
6 \\
50 \\
84 \\
40\end{array}$ & $\begin{array}{r}0.5 \\
10.7 \\
6.4 \\
1.0 \\
7.9 \\
9.3 \\
21.9\end{array}$ & $\begin{array}{l}\text { Hernia } \\
\text { Hernia } \\
\text { Inguinal hernia } \\
\text { Hernia } \\
\text { Duodenal ulcer } \\
\text { Duodenal ulcer } \\
\text { Pulmonary tuber- }\end{array}$ \\
\hline 16 & 38 & 57 & 78 & 11.8 & Neurosis \\
\hline
\end{tabular}

cluding the two cases with achlorhydria and low pepsin, the figures vary from 4.6 to $21.9 \mathrm{mgm}$., the median value for the group being $7.75 \mathrm{mgm}$. per cc. Obviously, a fasting expression is subject to so many inconstant factors that a determination of its content seems to be of relatively little value.

For the 81 cases examined one hour after an Ewald meal the median value for pepsin was 3.9 mgm. per cc. and for free acid 33.

\section{DISCUSSION}

In considering the secretion of pepsin by the stomach, it seems important to point out the practical differences between peptic activity and the concentration of pepsin. It is known that the optimum $\mathrm{pH}$ for peptic activity is between 1.9 and 2.3 , and that outside of this range digestive action rapidly diminishes. It will be noted that in the method we have used, the $\mathrm{pH}$ of the digestion mixture may vary slightly with differences in acidity of the juices to be tested. But since the hemoglobin used is in solution in approximately
$.06 \mathrm{~N} \mathrm{HCl}$, and $5 \mathrm{cc}$. are used for $1 \mathrm{cc}$. of gastric juice, the change in $\mathrm{pH}$ is not outside the optimum range for peptic activity. Substantiating this, we have found that a commercial preparation of pepsin gives the same values whether dissolved in $\mathrm{N} / 10 \mathrm{HCl}, \mathrm{N} / 100 \mathrm{HCl}$ or in distilled water.

Our results measure the amount of pepsin secreted rather than the peptic activity in vivo, since artificial conditions are created whereby the $\mathrm{pH}$ of the original juice as ordinarily encountered makes little or no difference in the result. Thus in cases of pernicious anemia, where the acidity is very low, the juice might show no peptic activity as found in the stomach but when analyzed as above shows appreciable amounts of pepsin. These facts may also explain why the range of values in our cases do not vary as much as those of other workers (4). A fairly accurate idea of the activity of any given juice in vivo can be obtained after considering the acidity and the amount of pepsin present.

Our results show a fairly high coefficient of correlation between the acid and pepsin secretion, viz. 0.74 for the entire group. In general, a high acid is likely to be accompanied by high pepsin and vice versa, but frequent exceptions are found. These findings are in general similar to those of Helmer, Fouts, and Zerfas (3), though these investigators lay more stress upon the frequent instances among their cases of dissociation of the acid and enzyme content.

The very low values for pepsin in pernicious anemia also confirm the results obtained by these investigators (5), though they used histamine as a stimulus.

As to the choice of stimulus used in studying pepsin secretion, it is known from the early work of Pavlov that among the foods bread is one of the most powerful stimulants of pepsin secretion. There is still some controversy as to whether histamine stimulates secretion of pepsin or not. Vineberg and Babkin (6), as well as Gilman and Cowgill (7), feel that it does not, but Polland and Bloomfield (8) have found an increase in the total pepsin output following the administration of histamine.

From this series of cases it seems clear that, in general, patients with duodenal ulcer secrete more pepsin than do those without ulcer. This 
is in accord with the work of Vanzant, Osterberg et al. (4), though we have not found as marked variations from the normal as they reported. We have not followed our patients long enough as yet to determine whether a high value for pepsin makes the prognosis less favorable, as these investigators believe. On the other hand, Polland and Bloomfield (9), in a small group of cases, noted no significant differences between the value for pepsin in cases with duodenal ulcer and in controls.

It would seem that pepsin determination in cases of carcinoma of the stomach is of little help in diagnosis, since it apparently reflects only the usual picture of hyposecretion as seen in the acid values.

\section{SUMMARY AND CONCLUSIONS}

1. A series of pepsin determinations, done according to the hemoglobin digestion method of Anson and Mirsky (2), is reported.

2. With the Ewald test meal the following results were obtained:

(a) In a miscellaneous group of patients the median value for pepsin was $3.6 \mathrm{mgm}$. per cc. of gastric juice and the median value for free acid was 31 .

(b) In a group of duodenal ulcers the median value for pepsin was $6.75 \mathrm{mgm}$. and for free acid 47.5 .

(c) In a small series of five postoperative ulcers the pepsin ranged from 0 to $3.4 \mathrm{mgm}$.

(d) In six cases with carcinoma of the stomach all, except one, had low concentrations of pepsin.

(e) Patients with pernicious anemia showed only traces of pepsin.

(f) The median value for pepsin for the entire group was $3.9 \mathrm{mgm}$. per cc. and for free acid was 33 .
3. Fasting gastric expressions gave rather marked variations in pepsin concentration, the median value being $7.75 \mathrm{mgm}$. per cc.

4. A high correlation existed between the acid and pepsin secretion in response to the test meal, though exceptions were not infrequent.

We are indebted to Dr. Michael Heidelberger and staff for assistance in preparing the chemical reagents used in the pepsin determinations.

\section{BIBLIOGRAPHY}

1. Howes, E. L., Flood, C. A., and Mullins, C. R., The influence of pepsin and hydrochloric acid on the healing of gastric defects-artificial gastric ulcer. (In press.)

2. Anson, M. L., and Mirsky, A. E., The estimation of pepsin with hemoglobin. J. Gen. Physiol., 1932, $16,59$.

3. Helmer, O. M., Fouts, P. J., and Zerfas, L. G., Gastro-intestinal studies. IV. The relation of $\mathrm{pH}$ to the pepsin and rennin content of the gastric juice. Am. J. Digest. Dis. and Nutrition, 1934, 1, 120.

4. Vanzant, F. R., Osterberg, A. E., Alvarez, W. C., and Rivers, A. B., Studies of gastric pepsin. II. Secretion of pepsin in cases of duodenal ulcer and pseudo-ulcer. J. Clin. Invest., 1933, 12, 557.

5. Helmer, O. M., Fouts, P. J., and Zerfas, L. G., Gastro-intestinal studies. I. Gastric juice in pernicious anemia. J. Clin. Invest., 1932, 11, 1129.

6. Vineberg, A. M., and Babkin, B. P., Histamine and pilocarpin in relation to the gastric secretion. Am. J. Physiol., 1931, 97, 69.

7. Gilman, A., and Cowgill, G. R., The effect of histamine upon the secretion of gastric pepsin. Am. J. Physiol., 1931, 97, 124.

8. Polland, W. S., and Bloomfield, A. L., Quantitative measurements of pepsin in gastric juice before and after histamine stimulation. J. Clin. Invest., 1929, $7,57$.

Polland, W. S., Stimulation of gastric pepsin by histamine. J. Clin. Invest., 1932, 11, 449.

9. Polland, W. S., and Bloomfield, A. L., The diagnostic value of determinations of pepsin in gastric juice. J. Clin. Invest., 1930, 9, 107. 